\title{
LETTER
}

\section{Sodicgedrite in ultrahigh-temperature Mg-Al-rich rocks from the Palghat-Cauvery Shear Zone system, southern India}

\author{
Toshiaki TsunOGAE ${ }^{* * *}$, M. SANTOSH ${ }^{* * *}$ and Makoto SHIMPO ${ }^{* * * *}$ \\ *Graduate School of Life and Environmental Sciences (Earth Evolution Sciences), \\ University of Tsukuba, Ibaraki 305-8572, Japan \\ *** Department of Geology, University of Johannesburg, P.O. Box 524, \\ Auckland Park 2006, Republic of South Africa \\ *** Department of Natural Environmental Science, Faculty of Science, Kochi University, \\ Akebono-cho 2-5-1, Kochi 780-8520, Japan \\ *****Master's Program in Education, University of Tsukuba, Ibaraki 305-8572, Japan
}

\begin{abstract}
We report high-Na gedrite (sodicgedrite) with up to $3.1 \mathrm{wt} \% \mathrm{Na}_{2} \mathrm{O}\left(\sim 0.81 \mathrm{Na}^{\mathrm{A}}\right.$ pfu) in ultrahigh-temperature (UHT) $\mathrm{Mg}^{-} \mathrm{Al}-$ rich rocks from the northern margin of the Pan-African Madurai Block along the Palghat ${ }^{-}$ Cauvery Shear Zone system, southern India. An amount of $\mathrm{Na}^{\mathrm{A}}$ of the gedrite increases with increasing $\mathrm{Al}^{\mathrm{IV}}$. The sum of $\mathrm{Na}^{\mathrm{A}}$ and $\mathrm{Al}^{\mathrm{IV}}$ also increases linearly with decreasing Si suggesting the substitution of $\mathrm{Na}^{\mathrm{A}} \mathrm{Al}^{\mathrm{IV}} \leftrightarrow \mathrm{Si}$. The negative correlation between $\mathrm{Fe}+\mathrm{Mg}+\mathrm{Si}$ and $\mathrm{Al}$ is probably due to the tschermak substitution $\left((\mathrm{Fe}, \mathrm{Mg})^{\mathrm{VI}} \mathrm{Si}^{\mathrm{IV}} \leftrightarrow \mathrm{Al}^{\mathrm{VI}} \mathrm{Al}^{\mathrm{IV}}\right)$. The relatively coarse-grained nature and porphyroblastic occurrence of the sodicgedrite suggest that the mineral recrystallized at the peak UHT metamorphism. In contrast, retrograde gedrite with cordierite is less sodic with 1.1-1.6 wt $\% \mathrm{Na}_{2} \mathrm{O}\left(\mathrm{Na}^{\mathrm{A}}=0.24-0.35 \mathrm{pfu}\right)$. Our data suggest that high- $\mathrm{Na}$ content in gedrite is a possible indicator of UHT metamorphism.
\end{abstract}

Keywords: Sodicgedrite, Ultrahigh-temperature metamorphism, Palghat-Cauvery Shear Zone system, Madurai Block, Pan-African, Gondwana, Southern India

\section{INTRODUCTION}

Gedrite is known as a common rock-forming mineral in $\mathrm{Mg}$-rich pelitic rocks that underwent amphibolite- to granulite-facies metamorphism. The mineral has also been reported in several $\mathrm{Mg}-\mathrm{Al}$-rich rocks from ultrahigh-temperature (UHT) metamorphic terranes (e.g., Harley, 1985; Ouzegane et al., 1996; Dasgupta et al., 1999). Such gedrite in UHT rocks generally contain high $\mathrm{Na}_{2} \mathrm{O}\left(\mathrm{Na}^{\mathrm{A}}>0.5\right)$ as sodicgedrite (Leake et al., 1997). The aim of this short report is to describe new occurrence and chemistry of extremely Na-rich gedrite $\left(\sim 3.1 \mathrm{wt} \% \mathrm{Na}_{2} \mathrm{O}\right)$ in $\mathrm{Mg}-\mathrm{Al}$-rich rocks from the northernmost flank of the Pan-African Madurai Block along the Palghat-Cauvery Shear Zone system (PCSS) in southern India. Such high$\mathrm{Na}$ gedrite has not been reported in previous studies from this area (cf., Koshimoto et al., 2004; Shimpo et al., 2006; Santosh and Sajeev, 2006) and from other UHT terranes. Shimpo et al. (2006) and Tsunogae and Santosh (2006)

doi:10.2465/jmps.060824

T. Tsunogae, tsunogae@arsia.geo.tsukuba.ac.jp Corresponding author

M. Santosh, santosh@cc.kochi-u.ac.jp reported near eclogite-facies high-pressure (HP) metamorphism at $P>12$ kbar and following UHT peak event of $T=940-990^{\circ} \mathrm{C}$ from the PCSS, which is probably related to Neoproterozoic continent-continent collision orogeny from this terrane. Available petrological data from adjacent areas along the PCSS also support such HP and UHT metamorphism (Tsunogae and Santosh, 2003; Santosh et al., 2004; Koshimoto et al., 2004; Santosh and Sajeev, 2006).

\section{PETROGRAPHY}

Gedrite-bearing $\mathrm{Mg}$ - $\mathrm{Al}$-rich rocks were collected from Malappatty (Karur District) and Sevitturangampatti (Namakkal District) in Tamil Nadu State. Localities of the examined samples are discussed in Tsunogae and Santosh (2003) and Shimpo et al. (2006), respectively. Below we summarize the petrography of six representative gedritebearing rocks from these areas.

Sample MD2-4B from Malappatty is composed of gedrite + biotite aggregate in the matrix of plagioclase. Fine-grained symplectitic intergrowth of cordierite and corundum occur between gedrite and biotite. Gedrite is 

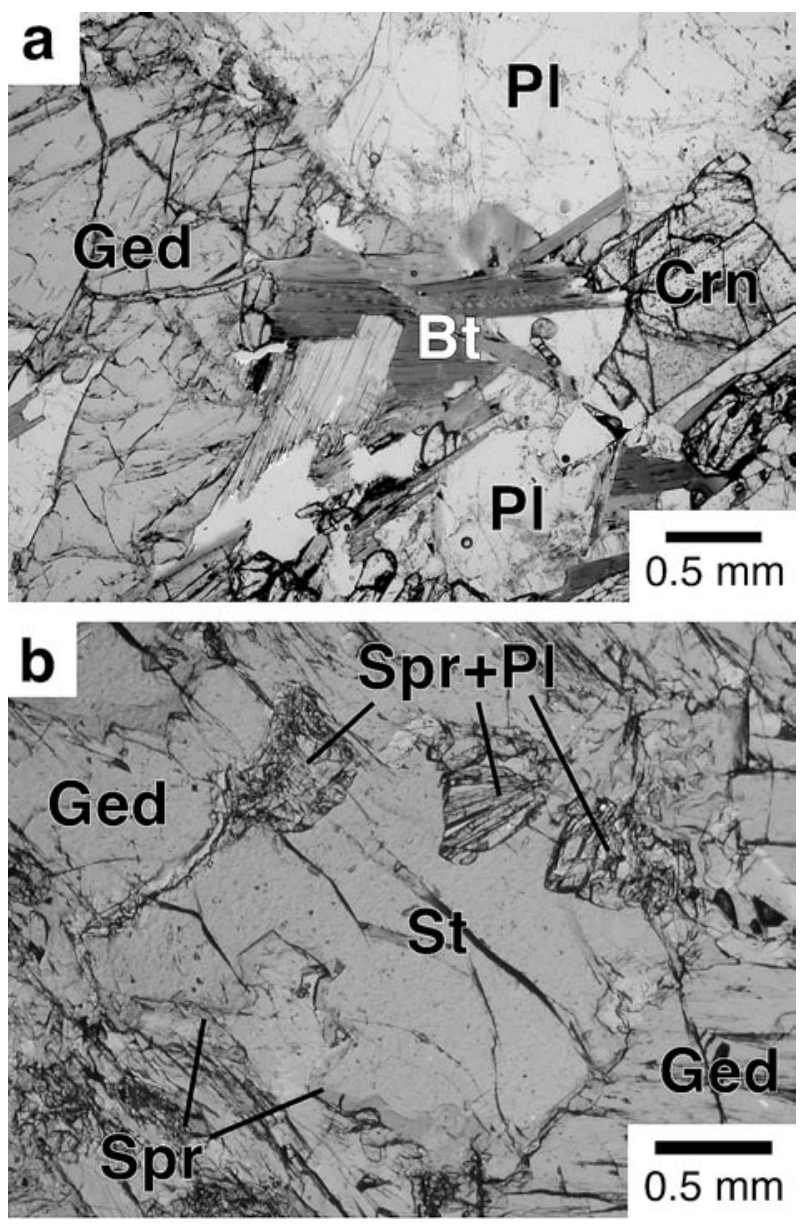

Figure 1. Photomicrographs of gedrite in $\mathrm{Mg}-\mathrm{Al}$-rich rocks from the Palghat-Cauvery Shear Zone system, southern India. (a) Gedrite (Ged) - biotite (Bt) - plagioclase (Pl) rock (sample MD2-4K) from Malappatty. Corundum (Crn) also occurs with plagioclase as an accessory phase. (b) Coarse-grained gedrite containing $\mathrm{Mg}$-rich staurolite $(\mathrm{St})$ in sample MD16-1P from Sevitturangampatti. Sapphirine (Spr) and plagioclase occur along the boundary between gedrite and staurolite.

coarse-grained $(\sim 4.5 \mathrm{~mm})$ and defines obvious foliation together with biotite in hand specimen. Sample MD2-4K from the same locality principally shows a similar gedrite-biotite-plagioclase assemblage (Fig. 1a), although the gedrite is smaller in size $(0.1-2.5 \mathrm{~mm})$. Plagioclase is more abundant $(30-40 \%)$ than that in sample MD2-4B and occasionally contains fine-grained $(<0.2 \mathrm{~mm})$ inclusions of isolated sapphirine and corundum.

Samples MD16-1A, G, P, and AU were collected from Sevitturangampatti locality. Sample MD16-1A is composed mainly of garnet, quartz, gedrite, and sillimanite. Gedrite occurs as medium-grained $(\sim 2 \mathrm{~mm})$ porphyroblasts defining the foliation together with sillimanite in the matrix of quartz. Garnet is in part mantled by cordierite suggesting a retrograde reaction: garnet + sillimanite + quartz $\rightarrow$ cordierite. Sample MD16-1G is composed of porphyroblasts of garnet, corundum, and sillimanite. Gedrite in this sample is medium-grained $(0.1-0.3 \mathrm{~mm})$ and occurs along the boundary between coarse-grained (up to $9 \mathrm{~mm}$ ) garnet and corundum. Retrograde cordierite, sapphirine, and spinel occur as fine-grained aggregates around garnet, corundum, and sillimanite. Rare kyanite and $\mathrm{Mg}$-rich staurolite are present only as inclusions in garnet as relic HP phases. Sample MD16-1P is characterized by coarse-grained $(\sim 3.5 \mathrm{~mm})$ gedrite that contains yellowish $\mathrm{Mg}$-rich staurolite in the matrix of cordierite $(\sim 3.0 \mathrm{~mm})$. Sapphirine and plagioclase occur along the boundary between gedrite and staurolite (Fig. 1b), suggesting sapphirine formation from the hydrous minerals. This texture confirms that gedrite is a prograde phase and probably underwent peak metamorphism. Gedrite in sample MD16-1AU (sillimanite-quartz rock) is obviously different from that in the other rocks because it is fine grained $(<0.2 \mathrm{~mm})$ and intergrows with cordierite around sillimanite as a retrograde phase.

\section{MINERAL CHEMISTRY}

Chemical analyses of gedrite were performed by electron microprobe analyzer (JEOL JXA8621) at the University of Tsukuba under conditions of $20 \mathrm{kV}$ accelerating voltage and $10 \mathrm{nA}$ sample current. Analysis of fluorine and chlorine followed the technique described in Tsunogae et al. (2003). Representative compositions of gedrite are given in Table 1. Gedrite in the examined samples shows wide variation in $\mathrm{Na}_{2} \mathrm{O}$ content from 1.0 to $3.1 \mathrm{wt} \%$ depending on lithology and mineral assemblage. The ration of $X_{\mathrm{Mg}}(=\mathrm{Mg} /(\mathrm{Mg}+\mathrm{Fe}))$ varies from 0.63 to 0.80 . Coarse-grained gedrite in sample MD2-4B from Malappatty shows the highest $\mathrm{Na}_{2} \mathrm{O}$ content of up to 3.1 wt $\%\left(\sim 0.82 \mathrm{Na}^{\mathrm{A}} \mathrm{pfu}\right)$, the highest yet reported from UHT terranes. Gedrite in sample MD16-1A associated with sillimanite is also $\mathrm{Na}$-bearing, although its $\mathrm{Na}_{2} \mathrm{O}$ content is slightly low, $\sim 2.8 \mathrm{wt} \%\left(\sim 0.72 \mathrm{Na}^{\mathrm{A}}\right.$ pfu $)$. In contrast, retrograde gedrite in sample MD16-1AU shows the lowest $\mathrm{Na}_{2} \mathrm{O}$ content of 1.1-1.6 wt\% $\left(\mathrm{Na}^{\mathrm{A}}=0.24-0.35\right)$ and the highest $X_{\mathrm{Mg}}$ (0.79-0.81) among the analyzed samples. Gedrite examined in this study is also characterized by high $\mathrm{Al}$ contents (up to $2.34 \mathrm{Al}^{\mathrm{IV}}$ ).

Compositions of the analyzed gedrites are shown in diagrams (Fig. 2) together with representative compositions of gedrite in silica-deficient granulite-facies rocks from other localities. $\mathrm{Na}^{\mathrm{A}}$ content of gedrite in all samples increases with increasing $\mathrm{Al}^{\mathrm{IV}}$ as reported by Robinson et al. (1971) (Fig. 2a). The sum of $\mathrm{Na}^{\mathrm{A}}$ and $\mathrm{Al}^{\mathrm{IV}}$ also increases linearly with decreasing $\mathrm{Si}$ (Fig. 2b) as a result of the substitution of $\mathrm{Na}^{\mathrm{A}} \mathrm{Al}^{\mathrm{IV}} \leftrightarrow \mathrm{Si}$. The negative correlation between $\mathrm{Fe}+\mathrm{Mg}+\mathrm{Si}$ and $\mathrm{Al}$ (Fig. 2c) is probably due to 
Table 1. Representative electron microprobe analyses of gedrite from Malappatty and Sevitturangampatti, southern India

\begin{tabular}{|c|c|c|c|c|c|c|}
\hline $\begin{array}{l}\text { Sample No. } \\
\mathrm{O}^{*}\end{array}$ & $\begin{array}{r}\text { MD2-4B } \\
23 \\
\end{array}$ & $\begin{array}{r}\text { MD2-4K } \\
23 \\
\end{array}$ & $\begin{array}{r}\text { MD16-1A } \\
23 \\
\end{array}$ & $\begin{array}{r}\text { MD16-1G } \\
23 \\
\end{array}$ & $\begin{array}{r}\text { MD16-1P } \\
23 \\
\end{array}$ & $\begin{array}{r}\text { MD16-1AU } \\
23 \\
\end{array}$ \\
\hline $\mathrm{SiO}_{2}$ & 39.96 & 40.59 & 40.93 & 40.24 & 41.84 & 47.06 \\
\hline $\mathrm{Al}_{2} \mathrm{O}_{3}$ & 23.18 & 22.99 & 22.04 & 22.28 & 21.64 & 15.82 \\
\hline $\mathrm{TiO}_{2}$ & 0.16 & 0.15 & 0.00 & 0.01 & 0.42 & 0.25 \\
\hline $\mathrm{Cr}_{2} \mathrm{O}_{3}$ & 0.00 & 0.06 & 0.02 & 0.00 & 0.18 & 0.00 \\
\hline $\mathrm{FeO}^{* *}$ & 12.95 & 11.67 & 14.83 & 15.34 & 9.57 & 9.67 \\
\hline $\mathrm{MnO}$ & 0.06 & 0.12 & 0.10 & 0.28 & 0.14 & 0.02 \\
\hline $\mathrm{MgO}$ & 18.44 & 18.93 & 17.21 & 16.71 & 20.10 & 22.09 \\
\hline $\mathrm{CaO}$ & 0.06 & 0.02 & 0.16 & 0.44 & 0.45 & 0.13 \\
\hline $\mathrm{Na}_{2} \mathrm{O}$ & 3.02 & 3.06 & 2.76 & 2.53 & 2.56 & 1.09 \\
\hline $\mathrm{K}_{2} \mathrm{O}$ & 0.00 & 0.00 & 0.00 & 0.00 & 0.00 & 0.00 \\
\hline $\mathrm{F}$ & 0.03 & 0.03 & 0.03 & 0.01 & 0.11 & 0.03 \\
\hline$-\mathrm{O}$ & -0.01 & -0.01 & -0.01 & -0.01 & -0.05 & -0.01 \\
\hline $\mathrm{Cl}$ & $<0.01$ & 0.01 & 0.00 & 0.02 & 0.01 & $<0.01$ \\
\hline$-\mathrm{O}$ & 0.00 & 0.00 & 0.00 & 0.00 & 0.00 & 0.00 \\
\hline Total & 97.85 & 97.62 & 98.07 & 97.84 & 97.01 & 96.15 \\
\hline $\mathrm{Si}$ & 5.657 & 5.722 & 5.818 & 5.758 & 5.876 & 6.573 \\
\hline $\mathrm{Al}^{\mathrm{IV}}$ & 2.343 & 2.278 & 2.182 & 2.242 & 2.124 & 1.427 \\
\hline $\mathrm{T}$ total & 8.000 & 8.000 & 8.000 & 8.000 & 8.000 & 8.000 \\
\hline $\mathrm{Al}^{\mathrm{VI}}$ & 1.525 & 1.541 & 1.510 & 1.514 & 1.456 & 1.178 \\
\hline $\mathrm{Ti}$ & 0.016 & 0.016 & 0.000 & 0.001 & 0.044 & 0.027 \\
\hline $\mathrm{Cr}$ & 0.000 & 0.007 & 0.002 & 0.000 & 0.020 & 0.000 \\
\hline $\mathrm{Fe}$ & 1.533 & 1.376 & 1.762 & 1.835 & 1.123 & 1.129 \\
\hline $\mathrm{Mn}$ & 0.008 & 0.015 & 0.012 & 0.034 & 0.016 & 0.002 \\
\hline $\mathrm{Mg}$ & 3.888 & 3.975 & 3.645 & 3.562 & 4.204 & 4.595 \\
\hline $\mathrm{Ca}$ & 0.009 & 0.003 & 0.025 & 0.068 & 0.067 & 0.020 \\
\hline $\mathrm{Na}^{\mathrm{B}}$ & 0.021 & 0.068 & 0.044 & 0.000 & 0.069 & 0.050 \\
\hline $\mathrm{B}+\mathrm{C}$ total & 7.000 & 7.000 & 7.000 & 7.013 & 7.000 & 7.000 \\
\hline $\mathrm{Na}^{\mathrm{A}}$ & 0.806 & 0.767 & 0.715 & 0.702 & 0.629 & 0.245 \\
\hline K & 0.000 & 0.000 & 0.000 & 0.000 & 0.000 & 0.001 \\
\hline Total & 15.806 & 15.767 & 15.715 & 15.715 & 15.629 & 15.246 \\
\hline $\mathrm{F}$ & 0.015 & 0.012 & 0.015 & 0.006 & 0.048 & 0.012 \\
\hline $\mathrm{Cl}$ & 0.001 & 0.001 & 0.000 & 0.004 & 0.003 & $<0.001$ \\
\hline $\mathrm{Mg} /(\mathrm{Fe}+\mathrm{Mg})$ & 0.717 & 0.743 & 0.674 & 0.660 & 0.789 & 0.803 \\
\hline
\end{tabular}

* Number of oxygens.

*** Total Fe as FeO.

the tschermak substitution $\left((\mathrm{Fe}, \mathrm{Mg})^{\mathrm{VI}} \mathrm{Si}^{\mathrm{iV}} \leftrightarrow \mathrm{Al}^{\mathrm{VI}} \mathrm{Al}^{\mathrm{IV}}\right)$. $\mathrm{Na}$-rich gedrites from other localities principally have the same compositional trends. Although no obvious compositional zoning can be seen within single gedrite crystal, $X_{\mathrm{Mg}}$ and $\mathrm{Na}^{\mathrm{A}}$ slightly decrease from core to rim in some grains. $\mathrm{F}$ and $\mathrm{Cl}$ contents of the mineral are very low (less than 0.13 and $0.03 \mathrm{wt} \%$, respectively).

\section{DISCUSSION}

$\mathrm{Mg}-\mathrm{Al}$-rich rocks from the northern Madurai Block along the Palghat-Cauvery Shear Zone system in southern India contain sodicgedrite with extremely high-Na contents of up to $3.1 \mathrm{wt} \% \mathrm{Na}_{2} \mathrm{O}\left(\mathrm{Na}^{\mathrm{A}} \sim 0.82 \mathrm{pfu}\right)$. Such sodicgedrite with $\mathrm{Na}^{\mathrm{A}}>0.8$ pfu has been reported in meta-dolerite or hydrothermal vein in granite (e.g., Otten, 1984; Damman,
1989), but not from UHT terranes so far. Although the origin of sodicgedrite in UHT terrane is not well understood, some studies suggest that gedrites in UHT rocks are of retrograde in origin, related to the activity of $\mathrm{Na}^{-}$ bearing fluid along shear zones. For example, Harley (1985) reported gedrite (with up to $1.8 \mathrm{wt} \% \mathrm{Na}_{2} \mathrm{O}$ ) + garnet + kyanite (or cordierite) + quartz assemblage in gneisses from the Napier Complex of East Antarctica. As the rocks are collected from the vicinity of shear zones, Harley (1985) discussed that the gedrite is a product of later shearing. Dasgupta et al. (1999) also reported gedrite with up to $2.6 \mathrm{wt} \% \mathrm{Na}_{2} \mathrm{O}$ in sheared rocks from the Eastern Ghats Belt, India. Although a metasomatic origin through the activity of fluids along shear zones is a possible mechanism to explain the occurrence of sodicgedrite in our samples, halogen analyses of the gedrites demon- 

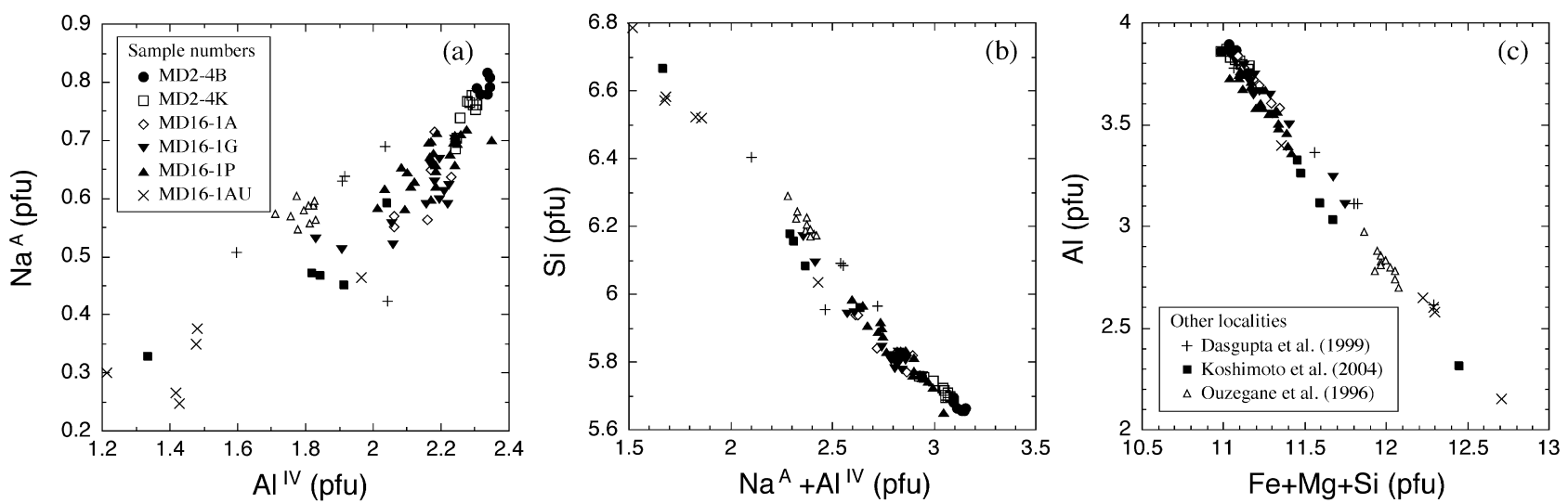

Figure 2. Compositional diagrams showing gedrite chemistry. Available compositional data of Na-bearing gedrite in silica-deficient granulitefacies rocks from Eastern Ghats (Dasgupta et al., 1999), Karur (Koshimoto et al., 2004), and In Ouzzal (Ouzegane et al., 1996) are also shown. (a) $\mathrm{Al}^{\mathrm{IV}}$ vs. $\mathrm{Na}^{\mathrm{A}}$ diagram, (b) $\mathrm{Na}^{\mathrm{A}}+\mathrm{Al}^{\mathrm{IV}}$ vs. Si diagram, (c) $\mathrm{Fe}+\mathrm{Mg}+\mathrm{Si}$ and $\mathrm{Al}$ diagram.

strate that the examined sodicgedrites are free from $\mathrm{Cl}$. This suggests that hydrothermal alteration by infiltration of a brine-rich fluid is not the cause of formation of our sodicgedrite. Although infiltration of retrograde aqueous fluid could have formed gedrite, such a later gedrite can be texturally distinguished from earlier phases because of its fine-grained nature and close relation with cordierite (e.g., sample MD16-1AU). Alternatively, Goscombe (1992) reported relic prograde gedrite $\left(\mathrm{Na}_{2} \mathrm{O}=2.3-2.8\right.$ wt\%) surrounded by sapphirine in silica-undersaturated rock from NE Strangways Range, Australia. Ouzegane et al. (1996) also reported primary gedrite with up to 2.1 $\mathrm{wt} \% \mathrm{Na}_{2} \mathrm{O}$ in gedrite-garnet-sillimanite granulite from In Ouzzal, Algeria. Their thermodynamic calculations indicate that the gedrite was stable at the peak metamorphism, 7-9 kbar and 850-900 ${ }^{\circ} \mathrm{C}$. Previous reports therefore confirmed that sodicgedrite formed at various stages of metamorphism, and some of the minerals are stable even at high-temperature $\left(\sim 900^{\circ} \mathrm{C}\right)$.

Relatively coarse-grained nature (samples MD4-2B and MD16-1P) and porphyroblastic occurrence together with sillimanite (sample MD16-1A) suggest that the sodicgedrite reported in this study was probably a stable phase during high-grade metamorphism, even at the peak UHT stage. Gedrite $+\mathrm{Mg}$-staurolite association and formation of sapphirine + plagioclase between gedrite and staurolite (Fig. 1b) discussed in the previous section confirmed that at least some gedrites are prograde products. In contrast, $\mathrm{Na}^{-}$and $\mathrm{Al}-$ poor gedrite with cordierite in sample MD16$1 \mathrm{AU}$ is regarded as a retrograde phase. The occurrence of high-Na gedrite which is texturally a high-grade phase in $\mathrm{Mg}-\mathrm{Al}-$ rich rocks is therefore regarded as a unique feature of UHT metamorphic rocks along the PCSS. Our gedrites probably did not decompose at such high-grade metamorphism because of their high-Na contents. The results sug- gest that high-Na content in gedrite in $\mathrm{Mg}$ - $\mathrm{Al}$-rich rocks is a possible indicator of UHT metamorphism. Additional experimental study of Na solubility in gedrite and thermodynamic calculations of sodicgedrite-bearing assemblages will be necessary to further address this interesting topic.

\section{ACKNOWLEDGMENTS}

We thank the staff at Gondwana Research Office in Trivandrum and Ms. Preetha Warrier for their helpful support, and Dr. N. Nishida for his assistance on microprobe analyses. This is a contribution to the Grant-in-Aid from the Japanese Ministry of Education, Sports, Culture, Science and Technology to Tsunogae (No. 17340158) and Santosh (No. 17403013). Dr. T. Hokada and an anonymous reviewer provided helpful comments that aided in improving our presentation. We thank these referees as well as Prof. E. Ohtani for his editorial comments.

\section{REFERENCES}

Damman, A.H. (1989) Hydrothermal orthoamphibole-bearing assemblages from the Gãsborn area, West Bergslagen, central Sweden. American Mineralogist, 74, 573-585.

Dasgupta, S., Sengupta, P., Sengupta, Pr., Ehl, J. and Raith, M. (1999) Petrology of gedrite-bearing rocks in mid-crustal ductile shear zones from Eastern Ghats Belt, India. Journal of Metamorphic Geology, 17, 765-778.

Goscombe, B. (1992) Silica-undersaturated sapphirine, spinel and kornerupine granulite facies rocks, NE Strangway Range, Central Australia. Journal of Metamorphic Geology, 10, 181201.

Harley, S.L. (1985) Paragenetic and mineral-chemical relationships in orthoamphibole-bearing gneisses from Enderby Land, East Antarctica: a record of Proterozoic uplift. Journal of Metamorphic Geology, 3, 179-200.

Koshimoto, S., Tsunogae, T. and Santosh, M. (2004) Sapphirine 
and corundum bearing ultrahigh temperature rocks from the northern domain of Palghat-Cauvery Shear System, southern India. Journal of Mineralogical and Petrological Sciences, 99, 298-310.

Leake, B.E., Woolley, A.R., Arps, C.E.S., Birch, W.D., Gilbert, M.C., Grice, J.D., Hawthorne, F.C., Kato, A., Kisch, H.J., Krivovichev, V.G., Linthout, K., Laird, J., Mandarino, J.A., Maresch, W.V., Nickel, E.H., Rock, N.M.S., Schumacher, J.C., Smith, D.C., Stephenson, N.C.N., Ungaretti, L., Whittaker, E.J.W. and Youzhi, G. (1997) Nomenclature of amphiboles: Report of the subcommittee on amphiboles of the International Mineralogical Association, commission on new minerals and mineral names. American Mineralogist, 82, 1019-1037.

Otten, M.T. (1984) Na-Al-rich gedrite coexisting with hornblende in a corona between plagioclase and olivine. American Mineralogist, 69, 458-464.

Ouzegane, K., Djemai, S. and Guiraud, M. (1996) Gedrite-garnet-sillimanite-bearing granulites from Amessmessa area, south In Ouzzal, Hoggar, Algeria. Journal of Metamorphic Geology, 14, 739-753.

Robinson, P., Ross, M. and Jaffe, H.W. (1971) Composition of the anthophyllite-gedrite series, comparisons of gedrite and hornblende, and the anthophyllite-gedrite solvus. American Mineralogist, 56, 1005-1041.

Santosh, M., Tsunogae, T. and Koshimoto, S. (2004) First report of sapphirine-bearing rocks from the Palghat-Cauvery Shear Zone System, Southern India. Gondwana Research, 7, 620-
626.

Santosh, M. and Sajeev, K. (2006) Anticlockwise evolution of ultrahigh-temperature granulites within continental collision zone in southern India. Lithos, 92, 447-464.

Shimpo, M., Tsunogae, T. and Santosh, M. (2006) First report of garnet-corundum rocks from Southern India: implications for prograde high-pressure (eclogite-facies?) metamorphism. Earth and Planetary Science Letters, 242, 111-129.

Tsunogae, T. and Santosh, M. (2003) Sapphirine and corundumbearing granulites from Karur, Madurai Block, Southern India. Gondwana Research, 6, 925-930.

Tsunogae, T., Osanai, Y., Owada, M., Toyoshima, T., Hokada, T. and Crowe, W.A. (2003) High fluorine pargasites in ultrahigh temperature granulites from Tonagh Island in the Archean Napier Complex, East Antarctica. Lithos, 70, 21-38.

Tsunogae, T. and Santosh, M. (2006) Reply to Comment on "First report of garnet-corundum rocks from Southern India: implications for prograde high-pressure (eclogite-facies?) metamorphism" by D.E. Kelsey, C. Clark, M. Hand, A.S. Collins. Earth and Planetary Science Letters, 249, 535-540.

Color version of Figures 1 is linked to the online version of the paper at http://www.jstage.jst.go.jp/browse/jmps

Manuscript received August 24, 2006

Manuscript accepted October 23, 2006

Published online January 19, 2007

Manuscript handled by Eiji Ohtani 